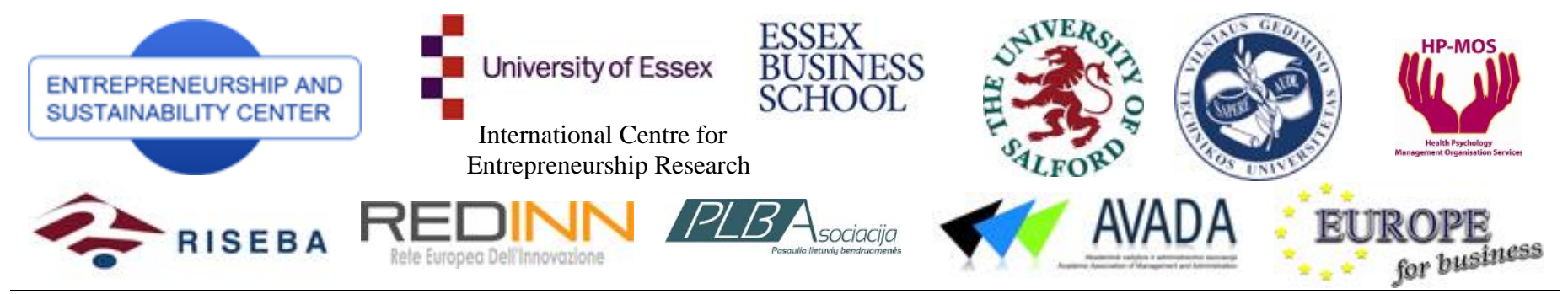

ISSN 2345-0282 (online) http://jssidoi.org/jesi/aims-and-scope-of-research/

\title{
SUSTAINABILITY OF COMMUNITY'S ENTREPRENEURSHIP: CASE OF FLOATING MARKET AT LADMAYOM
}

\author{
Supawadee Boonyachut \\ King Mongkut's University of Technology Thonburi, Thailand \\ E-mail: supawadee.boo@kmutt.ac.th
}

Received 20 August 2016; accepted 10 October 2016

\begin{abstract}
Ladmayom Market was created in 2003 by a community leader as an effort of sustaining the existing orchard to gain additional income among the villagers, and to maintain the existing life styles. Over a decade, the flea market was expanded around the original community floating market. Ladmayom Market, a one-man originated project, is currently a large market belonging to various land owners. The expansion of the market is sprawled according to the plot of lands. Because of this condition, the sustainability of the market declines as a whole due to its mixed up circulation, unpleasant patches of abandoned selling stalls, unequal business opportunity for merchants in some zones and lack of precise directions so that the customers easily lose their ways. Hence, this research regarded as a guide recommends a short term plan to sustain the community floating market by creating a better wayfinding. Its final result from all stakeholders who participated in public meeting and field survey is composed of directory, directional signs and other necessary categories for the market.
\end{abstract}

Keywords: floating market, stakeholders participation, community, entrepreneurship, short term plan, wayfinding, sustainability

Reference to this paper should be made as follows: Boonyachut, S. 2016. Sustainability of community's entrepreneurship: case of floating market at Ladmayom, Entrepreneurship and Sustainability Issues 4(2): 211-219.

DOI: http://dx.doi.org/10.9770/jesi.2016.4.2(8)

JEL Classifications: M20; M21

\section{Introduction}

Indicated in the interview with an expert in market business in Thailand, which was conducted on February AD 2011, a flea market became popular in the past five years predominantly during the period of unemployment and rising cost of gasoline. These two main reasons pushed the consumers to buy household and dairy items from the places close to their houses to save transportation expenses (Wattanawanyoo et al. 2012). Straight from work, they came and bought what they needed in their households such as daily food. There were meat, daily consumed food, preserved food, ready-to-serve food, desserts, costumes and low-cost household items which were not sold in the morning fresh market. Purchasing from flea markets, the consumers could also reduce their expenses due to cheaper costs of costumes, household appliances, costume jewelry, and decorative products. 
The flea market in Thailand is typically "an economic flea market" which is established along the side walk, in the open empty land, in the temple's plaza, or the office's plaza for the convenience of communities. Some flea markets are also located in the parking area of existing fresh markets or morning markets and supervised by professional management companies for commercial purposes. The establishment of flea market in a fresh market property would encourage as well as keep customers to come in both markets. Besides, the low-priced merchandises attract people from neighboring places to shop in flea markets during rotational days of selling. Subsequently, this provides more success to fresh markets becoming a part of each other (Boonyachut et al. 2011).

On the other hand, there are flea markets operating as "tourist flea markets". They have been established in agricultural areas by the community leaders so as to develop their community surroundings, and to encourage the villagers to gain additional profit from selling fruits, and vegetables grown in their lands. Ladmayom Market is one of these types, "tourist flea markets" (Boonyachut et al. 2011). In terms of an average merchant's income, it has more success than the economic flea market (Boonyachut et al. 2011).

\section{Literature Review}

Ladmayom Market, which is an orchard community, is located in Bangkok. The name of the canal, Ladmayom, has become a "geographical identification" of this market. It is a medium-sized market (Boonyachut et al. 2011) of about nine acres located on Bang Ramat Road in the Taling Chan district on the west side of Bangkok. The drive from Victory Monument, which is considered a city center, is 18 kilometers and takes approximately 33 minutes in normal traffic condition.

From the previous study on "Community market fair: Efficient management and local creative economy", which used Ladmayom Market as one of the case studies, the researchers found that Ladmayom Market became known to the public as the community leader's objective to encourage outsiders in promoting environmental preservation project on the basis of the villagers' campaign and goal for a clean canal. The community leader started the project by collecting garbage along Ladmayom canal. Then, he persuaded the villagers to sell their orchard products such as fruits, vegetables, and flowers so as to gain additional income, and join the creative activities around their community on weekends. When the community was alerted towards further pace, he conjoined the Ladmayom community market with the local administration tourism network, the Talingchan floating market network. The market is idealized as a "floating market of merit without cigarettes, liquor and beer being sold", and it operates at an average of 2 days a week on the weekends and any public holidays. The orchard goods and provisions on floating boats are sold along the Ladmayom canal whereas the luxury items are sold on land along both sides of the canal and on both sides of road that cuts through the community. Besides, the villagers can gain a higher average income than the merchants in other economic flea markets, which open at an average of more than 3 days a week. Thus, this indicates that the tourist flea market has more success than the economic flea market (Boonyachut et al. 2011). The success of Ladmayom Market leads to its rapid expansion. Nowadays, the market expands to seven zones owned by seven land owners connecting their areas to the original market place.

Most of the Ladmayom Market's merchants live around the community. They travel not more than 10 kilometers distance to sell their goods at Ladmayom Market as their sideline job. The merchants are the lower middle class group classified according to their income and working age range, 21-50 years old. A little over one-tenth of the merchants are high school educated individuals while the rest are educated higher. Three quarters of the customers coming to the market are casual customers, and a quarter of those are regular customers. Most of the customers come from afar; they travel 10 to 20 kilometers to the market. Some travel farther than 20 kilometers up to 70 kilometers. They are also the lower middle class group that is categorized by their income. Less than one-tenth of the customers are high school educated individuals while the rest are educated higher. The customers of all ages include working people, family groups, elderly, children, teenagers and students. Customers get pleasure from the activities such as horse riding, rowing boat to view the orchard and the temple along the canal, 
walking tour to see the old houses in the orchard scenery, teaching English to interested people, listening to a discourse on the day of the match, feeding a buffalo, and reading book in the informal library.

The rapid expansion of Ladmayom Market into many zones is detracted from the good intent of the original market aim. Likewise, the market development is geared in the direction of gaining quick benefits after the severe flooding which occurred during the 2011 monsoon season in Thailand. On this condition, the sustainability of the market declines as a whole caused by mixed-up circulation, unpleasant patches of abandoned selling stalls and unequal business opportunity for merchants in some zones (Boonyachut et al. 2012). The previous research, "Community market fair: Efficient management and local creative economy", adapted stakeholder participation from The Weave - Participatory Process Design Guide for Strategic Sustainable Development )v1( (Meisterheim et al. 2011) and "The New Guide to Identity" (Olin 2011). The conclusion derived from stakeholders, community leader, land owners, merchants, and customers was to move the market in the direction of "Maintaining the present lifestyle and orchard community, and earning additional income on the weekends" (Boonyachut 2016). Thus, Ladmayom Market should be a good prototype for those communities aiming to develop strong and responsive organizations. However, the sprawling market expansion needs both short term and long term plans to sustain the coexistence of commercial and orchard lifestyles in Ladmayom Floating Market as concluded in previous research. The previous research recommended a long term plan (Boonyachut 2016) in which its achievement requires the negotiation and compromise among landowners, and the acquisition of necessary funds and permits from the local administration. Therefore, this research is set to propose the short term plan to sustain the community floating market in Ladmayom while the long term plan is initiated.

\section{Methodologies}

The following methods were used in the research:

(1) Literature review from previous research to understand all groups of stakeholders and the factors which have brought them to Ladmayom Market, and the market direction;

(2) Observation;

(3) Identifying problems and analysis;

(4) Finding result to solve problems. The research utilizes two methods to serve different purposes (Meisterheim et al. 2011) and to ensure the involvement of all stakeholder groups (Kemmis, McTaggart 2005).

- The public meeting participated by available stakeholders

- The field survey

It is a recognized fact that stakeholder participation is necessary to make the community sustain (Taștan, Ciravoğlu 2016). The sample group for field survey is determined (Krejcie, Morgan 1970) and the data are analyzed using SPSS software. The statistics used for data analysis includes frequency, percentage, mean, standard deviation, and Pearson correlation coefficient; and

(5) Conclusion.

\section{Finding Problems and Analysis}

The researchers observe that there are problems in the market layout. The sprawling expansion causes mixed up circulation, misleading directions, and difficulty in communicating the meeting area in case a group of people go in separate ways. Since the market has been expanded without a plan, the main element to consider is to design many types of signage to direct the way easily. To address the problems, the market's layout is analyzed to derive necessary type and location of signage. There are many entry accesses to the market; hence, directories and signs showing directions of each zone are needed. Before designing signage, the zone or area identification should be done by naming all zones precisely. Thus, the appropriate method to name the zone is analyzed in three schemes: 
- The numbering scheme of the current zones in Ladmayom is shown in Figure 1a. The sequential number can be provided in the current zones; however, the future zonal expansion might not follow the current sequence, and the name scheme will then create confusion similar to the example shown in Figure $1 \mathrm{~b}$.

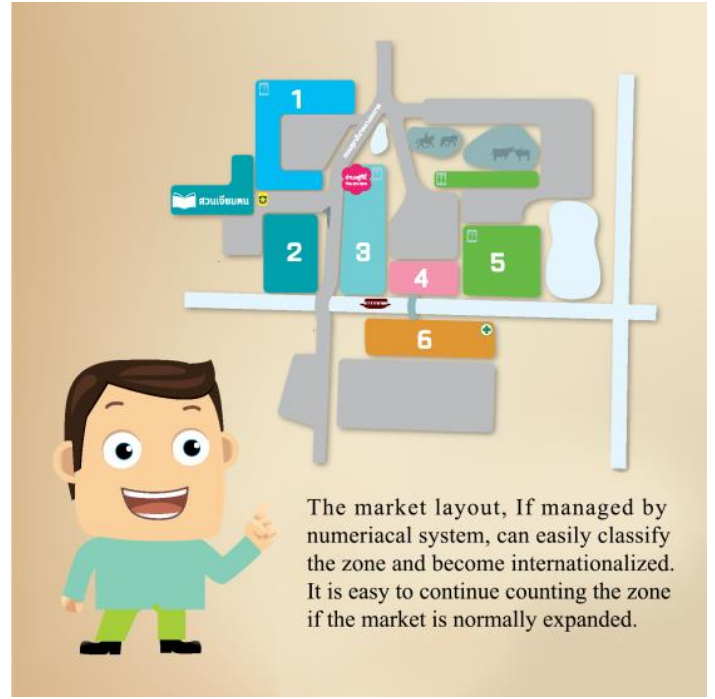

Figure 1a. Naming the zones by number in a regular expansion case

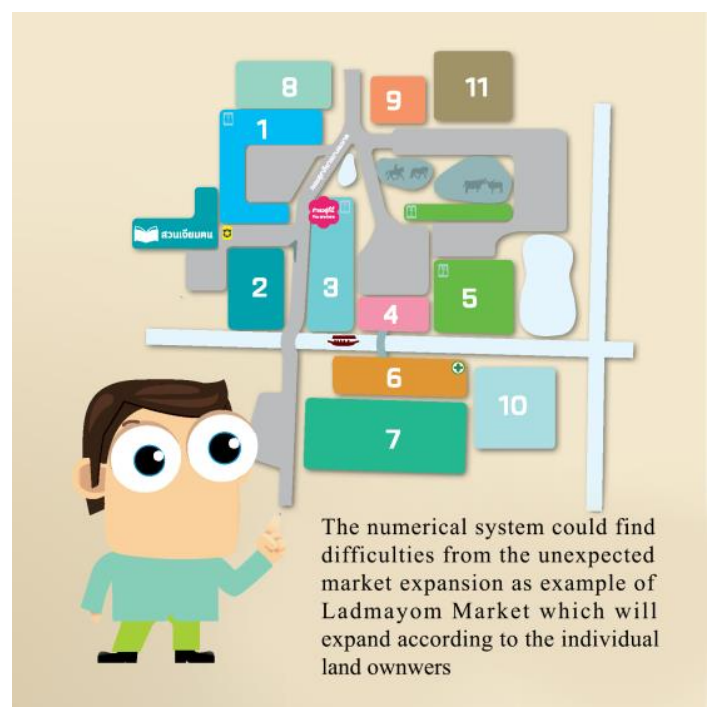

Figure 1b. Naming the zones by number in sprawling expansion case

- Naming the zone after the name of the land owner does not convey appropriate message to anyone-and also does not show the market identity (Cross 1994, eHow Arts \& Entertainment Editor 2011).

- $\quad$ Naming the zone as part of brand identity for Ladmayom Market

\section{Finding Result}

To come up with a collaborative idea to design zone identification or naming zone as part of brand identity for Ladmayom Market (Olin 2011, Boonyachut et al. 2013), the researchers have a critical analysis and serious discussion with community leader and land owners. Their preference is that the name of the zone begins with "Mayom", which means star gooseberry in English, because it is related to the name of the market "Lad+Mayom". The second word in the zone name will identify the character of location, merchant, and other categories associated to the market such as "shady", "joyfully", and "smiley". The researchers designed the icons to represent the zone name in three schemes as shown in Figure 2. The scheme that was selected by stakeholders is the one on the left column of Figure 2. The selected icons have clear representation of the star gooseberry with not much content and easiest of all to understand. 

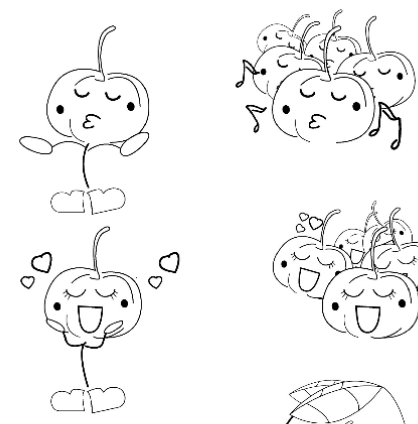

มะยม

สบายๆ

comfortably
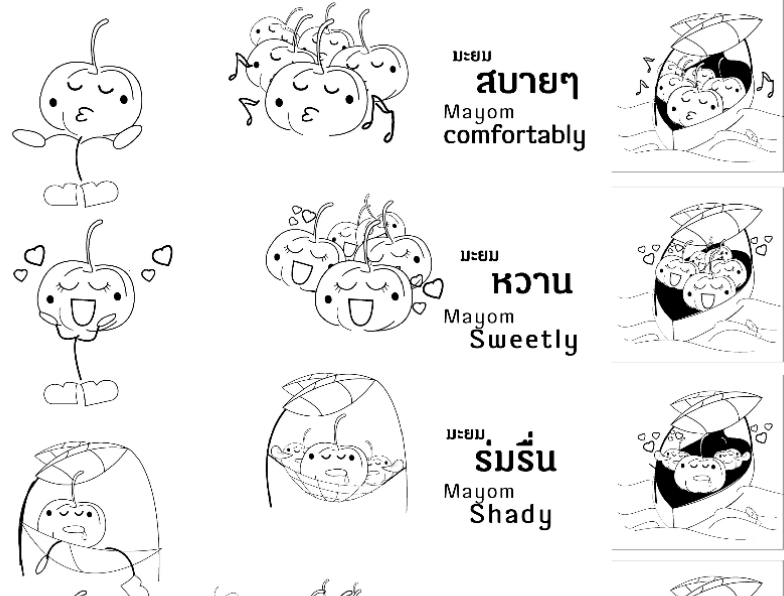

Suș Mayom
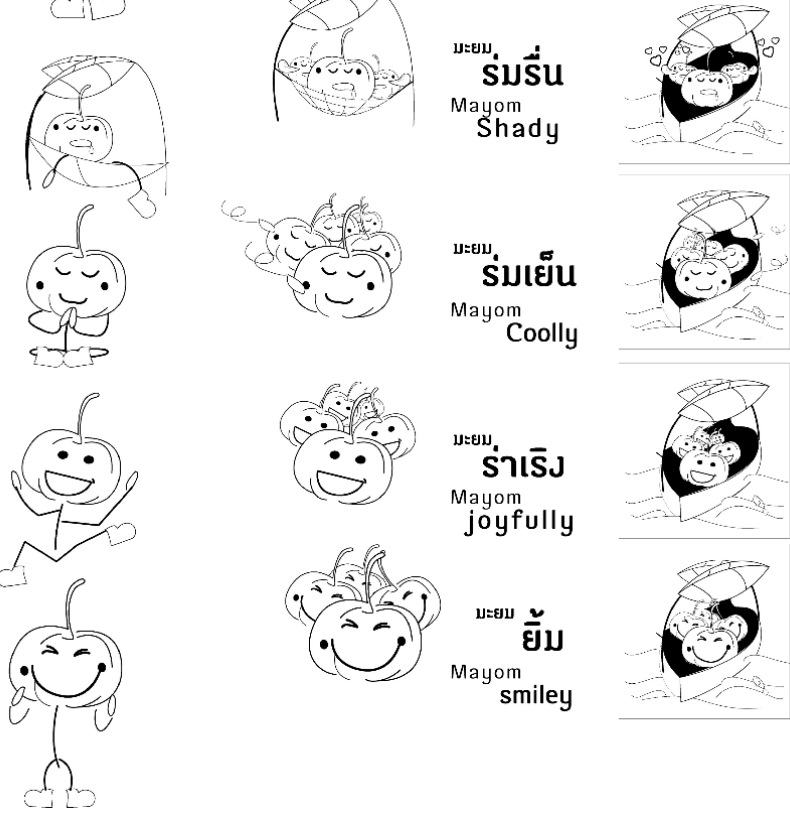

มะยม, ร่าเริ Mayom joyfully
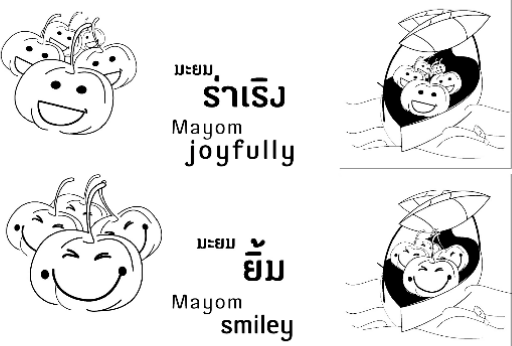

Figure 2. Designed by researchers, the icons representing the zone name with images related to star gooseberry fruit, Mayom, as a brand identity for Ladmayom Market are provided for stakeholders to select

Consequently, all elements such as icon, lettering, and color are put together under the concept of little content. The color of each zone will be different, so it's easy to remember and to read labels. The color is controlled in a comfortable tone to fit the theme of weekend market, explicitly, not too flashy look which will not fit to local market. The public meeting to hear comments pertaining to all elements in the sign involves the community leader, land owners, and merchants, only in a total of 20 persons. The public meeting receives satisfaction result for the overall aspect of the sign.

Due to lack of available time, the customers are not involved in the public meeting. Therefore, the field survey consisting of a number of questions based on the resolutions made during the public meeting is conducted. The signage tested in the field survey is composed of 3 directories and 10 directional signs installed in the locations as shown on the map in Figure 3. In the field survey, there are 255 respondents )from a group of costumers(. It also includes 55 merchants because most of them who are involved in the public meeting are also Ladmayom villagers. Thus, those merchants coming from other neighboring areas are also part of the stakeholder participation process. With 0.961 reliability level, the overall feature of the sign has gained acceptable satisfaction from three quarter of respondents. 


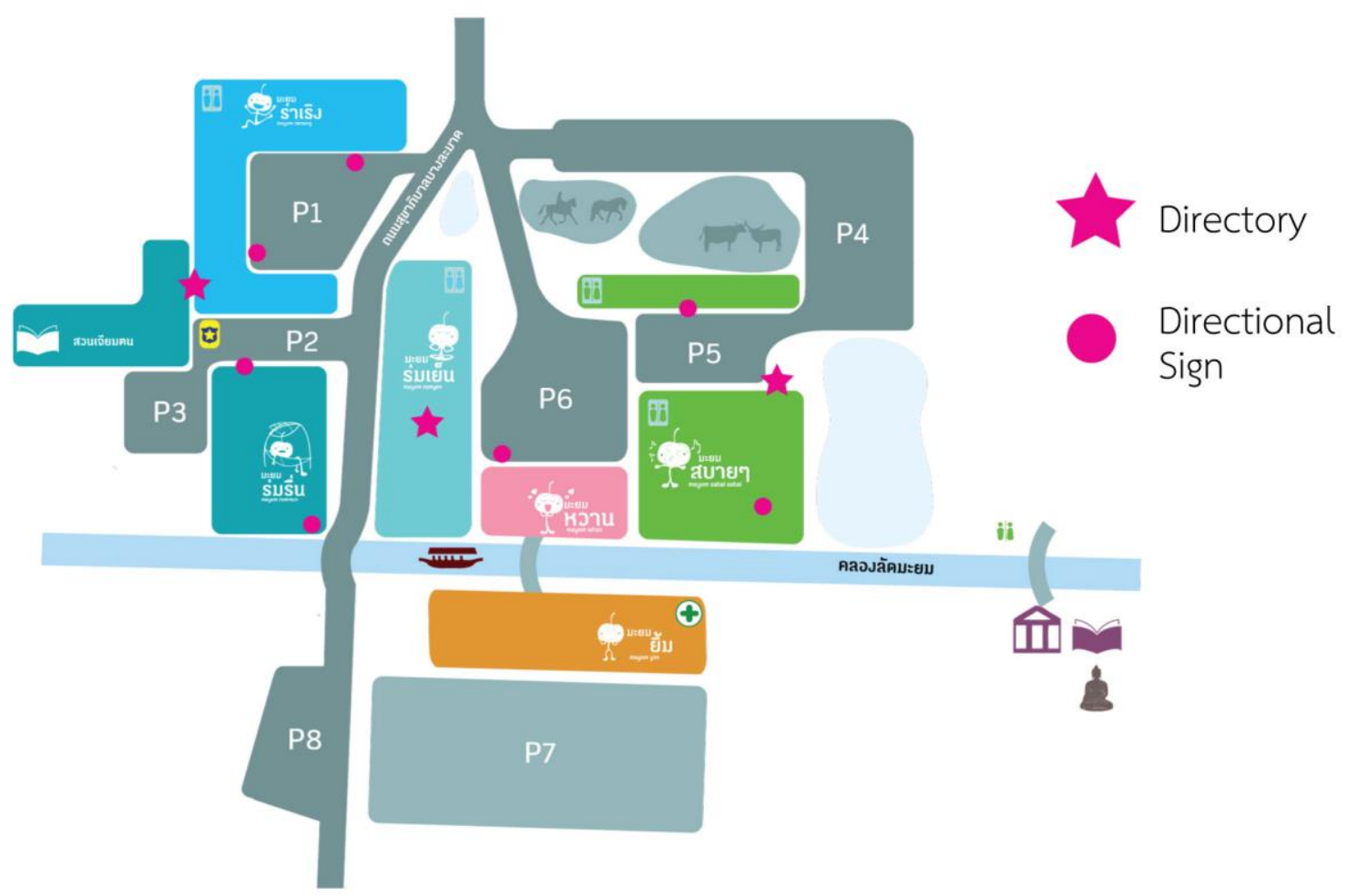

Figure 3. Location of the testing signs

On the other hand, there are several suggestions from respondents to adjust the size of the sign a little bigger and adding more signs in many other locations to avoid confusions and to designate zones accurately.

\section{Conclusions}

The final decision on zone name and signage design are concluded as shown in Figure 4a and the color of each zone will be different and suitable to the zone name. All colors are in a comfortable tone to fit the theme of weekend market and existing market logo (Boonyachut et al. 2013) designed in previous research by the same researcher team as shown on top of Figure $4 b$.

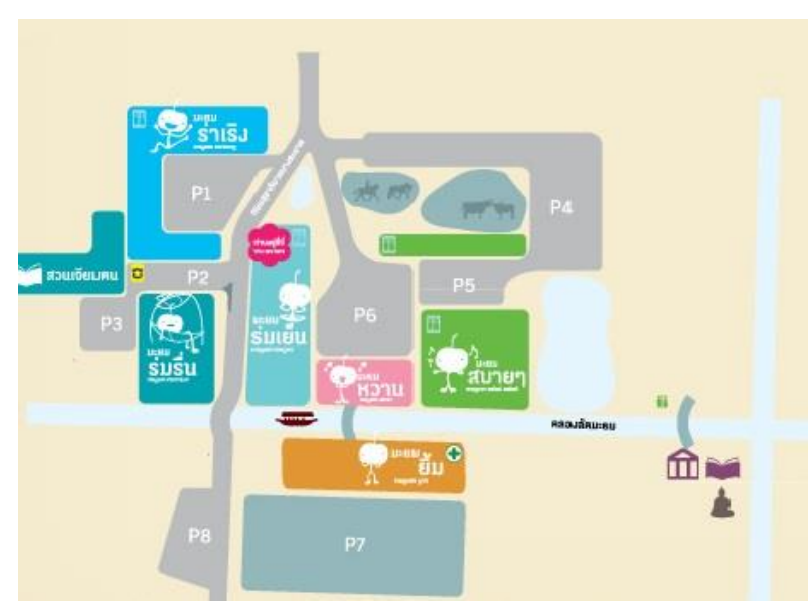

Figure 4a. Final scheme of zone name and color

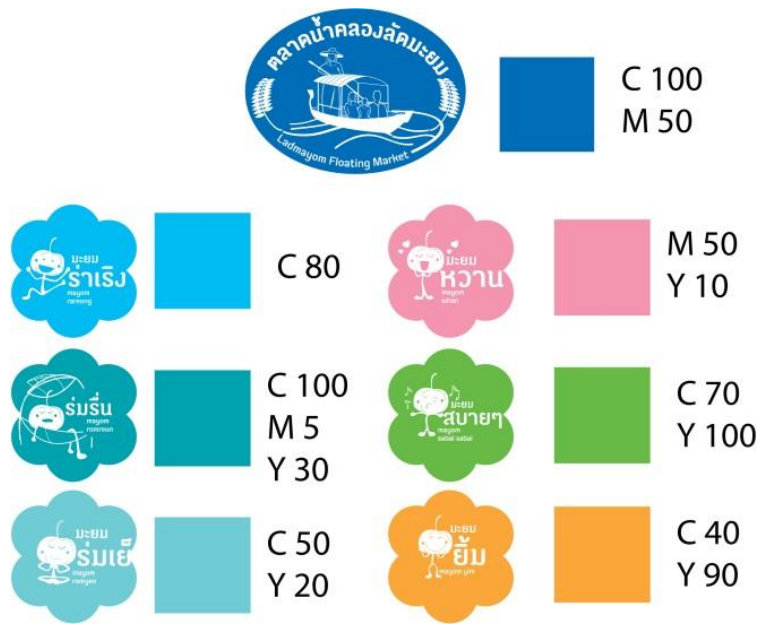

Figure 4b. Final color scheme of each zone 
The final design of directory and directional sign for the market as suggested by respondents are shown in Figure 5. Customers suggest more locations of wayfinding to ensure that they are not lost, and that they are able to reach their destinations. Other recommendations to be implemented as a short term plan of the market community include the following:

- Adding parking signs in the zones that are close to the parking area, as shown in Figure 6

- Adding directories in the front of toilets and all parking areas, as shown in Figure 6

- Having directory leaflets as free postcard and mini map

- Installing zone name sign in all selling stalls

- Pinning the zone name on each merchant's shirt

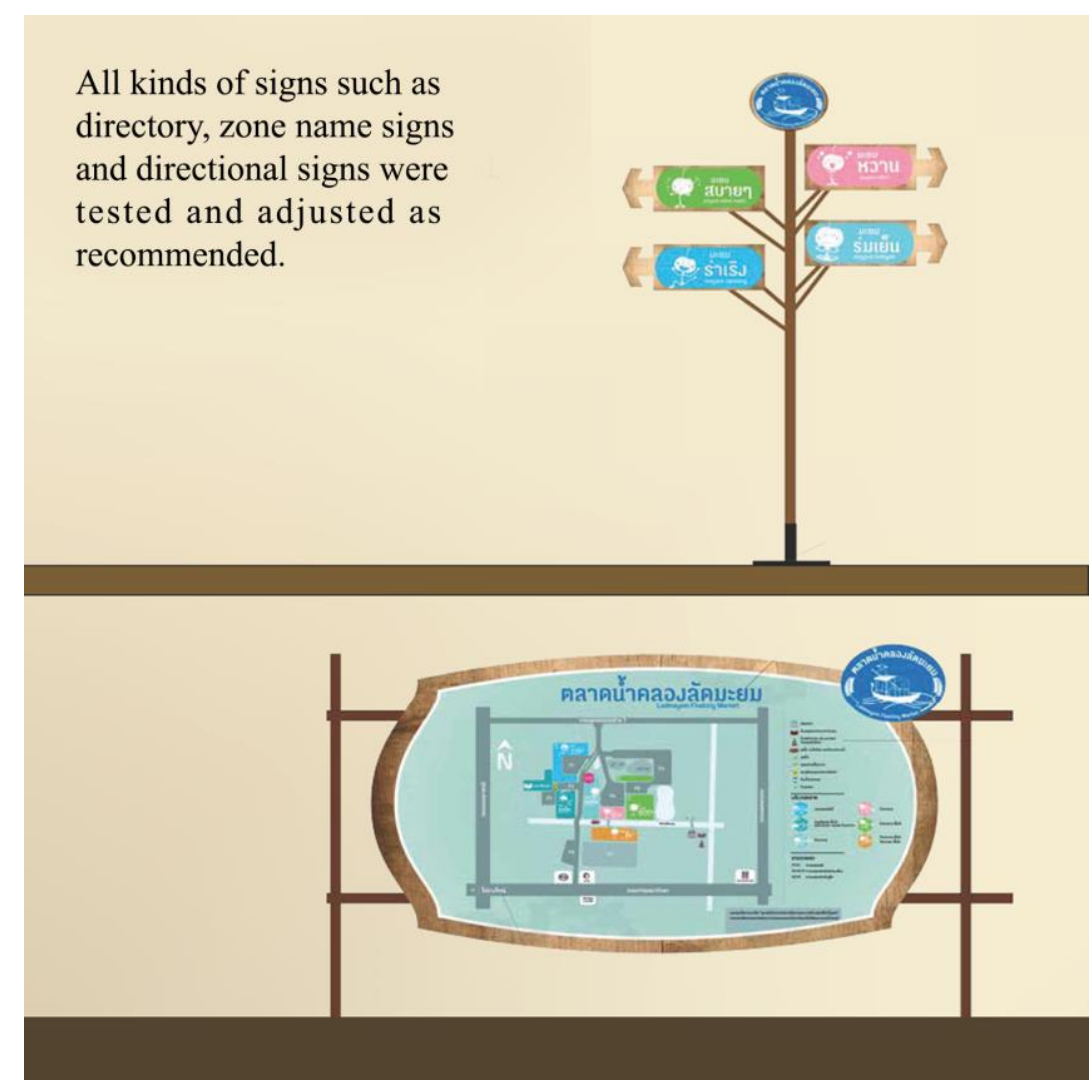

Figure 5. Final Directional Sign and Directory 


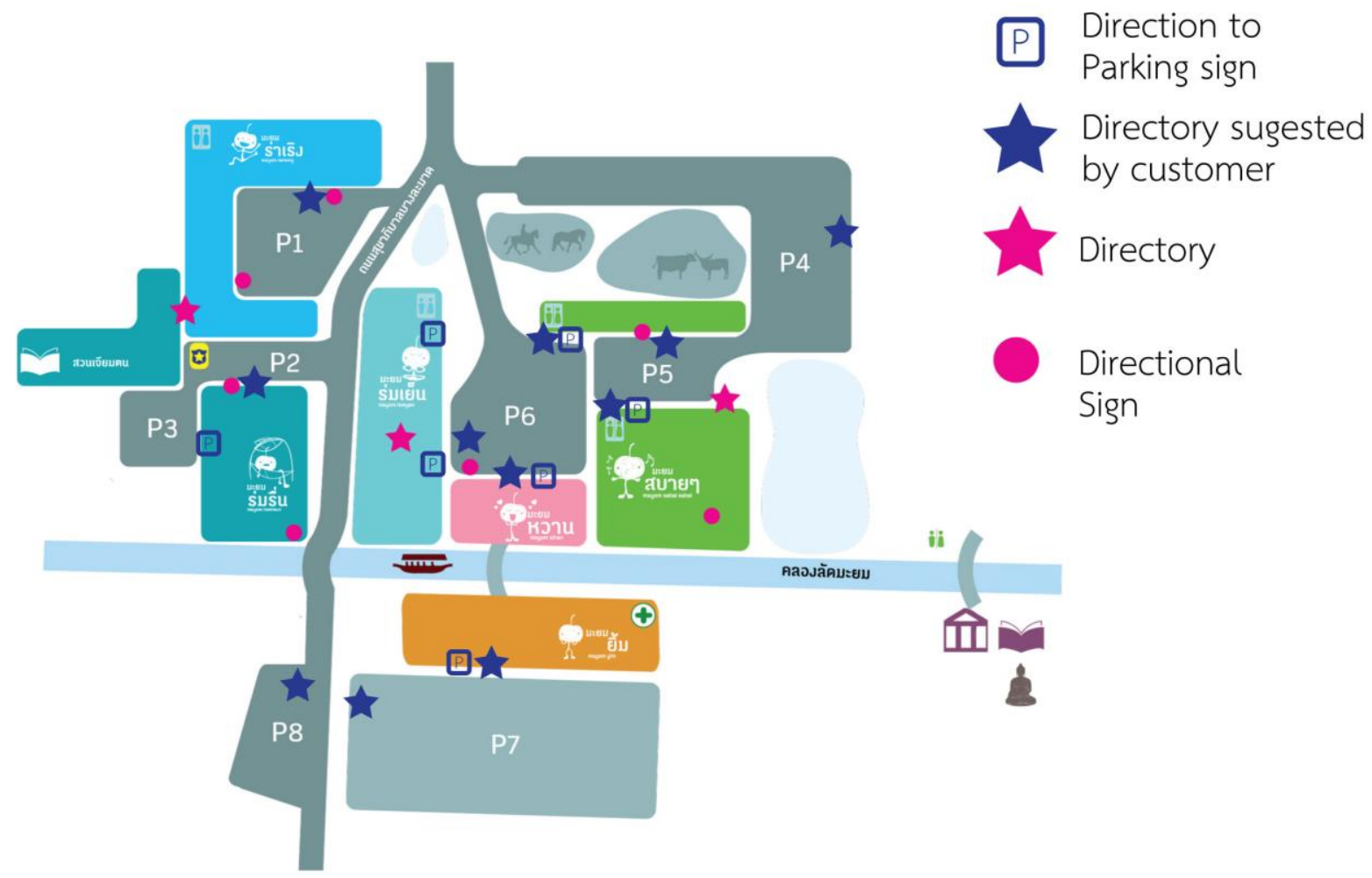

Figure 6. Directory and direction to parking sign in the locations recommended by the customers

\section{Suggestions}

The strong points of Ladmayom Market can emerge if the following conditions are considered:

- The good environment, i.e. The clean canal must attract customers to come in as usual.

- Good taste of food and good price make customers feel easy to pay.

- The efficient management within the market would make customers feel comfortable and willing to come again.

All of the aforementioned items and the short term plan in addition to this research result and long term plan of the previous research result can make the business successful and sustain the coexistence of commercial and orchard lifestyles in Ladmayom Floating Market. However, the knowledge transfer from academic to community's entrepreneurship is difficult (Ignatavičius et al. 2015) due to loose bonding between land owners as a cluster (Tvaronavičienè, Černevičiūte 2015; Razminienè et al. 2016).

\section{References}

Boonyachut, S. 2016. Coexistence of Commercial and Orchard Lifestyles in Ladmayom Floating Market. KMUTT Research And Development Journal, 39(2): 209.

Boonyachut, S.; Sunyavivat, C.; Wattanawanyoo, K. 2013. Derivation of Image Design from Social Backgrounds: A case study of community tourist flea market. The Inaugural European Conference on Arts and Humanities 2013 (ECAH2013): Selected papers, July 1821, Brighton, UK., 46-54. 
Boonyachut, S.; Wattanawanyoo, K.; Boonyachut, N.; \& Sunyavivat, C. 2011. Two forms of flea market: economic and tourist flea market. Journal of The National Research Council Of Thailand, 43(2): 125-141.

Cross, R.T. 1994. Iconicity and associative meaning: what are we looking for? Conference Proceedings of the 6th Biennial Conferences of ISAAC. Maastrict: ISAAC.

eHow Arts \& Entertainment Editor. How to Make a Pictogram. Available on the Internet: <http://www.ehow.com/how_2126159_makepictogram.html>.

Ignatavičius, R.; Tvaronavičienè, M.; Piccinetti, L. 2015. Sustainable development through technology transfer networks: case of Lithuania, Journal of Security and Sustainability Issues 4(3): 261-267. DOI: http://dx.doi.org/10.9770/jssi.2015.4.3(6)

Kemmis, S.: McTaggart, R. 2005. Participatory Action Research: Communicative Action and the Public Sphere. In N. K. Denzin \& Y.S.Lincoln (Eds.), London: SAGE Publications.

Krejcie, R. V.; Morgan, D. W. 1970. Determining Sample Size for Research Activities. Educational and Psychological Measurement 30(3): 607-610.

Meisterheim, T.; Cretney, C.; \& Cretney, A. 2011. The Weave (v1) - Participatory Process Design Guide for Strategic Sustainable Development. Available on the Internet: <http://womensplace.osu.edu/assets/files/TheWeave-July2011.pdf>.

Olin, W. 2011. The New Guide to Identity. UK: Published by MPG Books Group.

Razminienè, Kristina; Tvaronavičienė, Manuela; Zemlickienè, Vaida. 2016. Evaluation of cluster efficiency tool, Terra Economicus 14(3): 101-111. DOI: http://dx.doi.org/10.18522/2073-6606-2016-14-3-101-111

Taștan, H. \& Ciravoğlu, A. 2016. The Role of User Participation on Social Sustainability: A Case Study on Four Residential Areas. International Journal of Social, Behavioral, Educational, Economic, Business And Industrial Engineering, 10(1), $206-214$.

Tvaronavičienè, M.; Černevičiūtè, J. 2015. Technology transfer phenomenon and its impact on sustainable development, Journal of Security and Sustainability Issues 5(1): 87-97. http://dx.doi.org/10.9770/jssi.2015.5.1(7)

Wattanawanyoo, K.; Boonyachut, S.; Sunyavivat, C.; \& Boonyachut, N. 2012. Community market fair: efficient management and local creative economy. Bangkok: Published by King Mongkut's University of Technology Thonburi.

Supawadee BOONYACHUT - a fulltime instructor, Assistant Professor at the School of Architecture and Design, King Mongkut's University of Technology Thonburi, Thailand, completed Bachelor Degree in Architecture, graduated from the University of California, Los Angeles with a Master of Architecture, major in Design Theory and Methods. In addition to teaching the theory on Materials and Construction Technology, she is also a thesis advisor in Architecture program. Working in education field allows her to work effectively as a professional architect, teacher, writer, and researcher in different aspects and cross-disciplinary fields such as engineering, communication design, and social science. Her latest researches involved participatory process with stakeholders in the research communities. She wrote three books related to her researches in Thai. Two books are about materials and construction: the first one focuses on bilingual technical terms and the second is related to her previous cross-disciplinary research in engineering. The third book is a crossdisciplinary with communication design field.

Copyright (C) 2016 by author(s) and VsI Entrepreneurship and Sustainability Center This work is licensed under the Creative Commons Attribution International License (CC BY). http://creativecommons.org/licenses/by/4.0/ 